\title{
Carbohydrates in Leafy Spurge Roots as Influenced by
} Environment

\author{
RODNEY G. LYM AND CALVIN G. MESSERSMITH
}

\begin{abstract}
The total nonstructural carbohydrate (TNC) content of leafy spurce (Euphorbia esula L.) roots was determined for 4 consecutive growing seasons. The variations in water soluble (monosaccharide and disaccharide) and water insoluble or reserve carbohydrate content were compared to selected environmental parameters. TNC concentration reached maximum levels of $300 \mathrm{mg} / \mathrm{g}$ in midsummer and early fall, but declined rapidly to $190 \mathrm{mg} / \mathrm{g}$ or less late in the growing season. The soluble carbohydrates, mostly suerose, increased as the plant cold-hardened, while the insoluble carbohydrate content declined to near zero. Abrupt changes of root carbohydrate content could not be explained solely by the growth pattern of leafy spurge. Soluble carbohydrate content was high during periods favorable for growth, but insoluble reserves increased during periods of environmental stress. Root soluble carbohydrate content varied inversely with changes in the six day mean air temperature with an average partial correlation coefincient of $\mathbf{- 0 . 7 5}$. Soluble carbohydrate content inereased as the mean temperature decreased and declined as the mean temperature increased, but was independent of a specific temperature. The insoluble carbohydrate content was positively correlated with temperature. Root carbohydrate content also varied with fluctuations in the maximum and minimum temperature, dew point, and total pan evaporation, but not with precipitation.
\end{abstract}

Key Words: Euphorbia esula, cold hardiness, sucrose, climatic factors

Authors are assistant professor and professor of agronomy. North Dakota State University, Fargo, N.D. 58105.

The article is published with the approval of the Director, Agricultural Experiment Station, North Dakota State University as Journal Article No. 1524. Manuscript accepted 14 July 1986.
Carbohydrates are the primary source of reserve energy stored in biennial and perennial plants (Arny 1932). Analyzing concentrations and trends of carbohydrate storage can indicate periods when photosynthesis exceeds respiration and periods of plant stress such as drought (McIlroy 1967, Smith 1970).

Several researchers have shown that perennial weed species undergo seasonal variations in carbohydrate content (Agbakoba and Goodin 1969, Arny 1932, Bakke 1936, Barr 1940 and 1942). Root carbohydrate content of 5 perennial weed species declined sharply as growth began in the spring and reached a minimum level just prior to seed maturation. The low carbohydrate content generally was maintained until a rapid storage of carbohydrates began during cool fall weather and continued until topgrowth was killed by freezing temperatures. Bybee (1979) found that the nonstructural carbohydrate content in leafy spurge (Euphorbia esula L.) root samples taken at 2-week intervals changed abruptly through the growing season, and the variations did not occur during the same growth stage every year. Some fluctuation would be expected since the field samples were taken from a mature, heterogeneous infestation; however, the large and irregular fluctuations could not be explained solely on the basis of variation in sampling or the plant's growth cycle.

Total nonstructural carbohydrate (TNC) concentration is an estimate of the carbohydrate accumulation readily available for metabolism or translocation to other plant parts. These carbohydrates generally translocate as the water soluble monosaccharides glucose and fructose and the disaccharides sucrose and maltose (Smith 1981). Knowledge of likely periods of increased carbohydrate movement to the roots may help improve methods for long- 
term perennial weed control. Herbicide application coinciding with downward carbohydrate movement may result in increased herbicide translocation to the root system, since many herbicides travel in the phloem with the photosynthate (Agbakoba and Goodin 1969, Chang and VanderBorn 1968, Hunter and McIntyre 1974, Sharma et al. 1971). The purpose of this research was to determine the TNC content of leafy spurge roots and to compare the changes in water soluble and insoluble TNC with the growth cycle of the plant and with various environmental parameters for 4 consecutive growing seasons.

\section{Materials and Methods}

Leafy spurge samples were obtained from a natural infestation growing in Fargo, N.D. Three 0.5-kg samples were collected weekly in 1981 and 1982 and twice per week in 1983 and 1984 to a 15-cm depth. Sampling was started when shoots began to emerge in early April in 1981, 1983, and 1984 and early May 1982 and continued until late October of all years. Samples were taken at approximately $1300 \mathrm{~h}$ on each date. The samples were washed, frozen immediately, and stored until assayed for carbohydrates. Roots were oven dried at $62^{\circ} \mathrm{C}$ for $24 \mathrm{~h}$ and ground to a fine powder with a Wiley mill. TNC was extracted from $200 \mathrm{mg}$ samples by boiling in $15 \mathrm{ml}$ distilled water for $5 \mathrm{~min}$ followed by adding 10 $\mathrm{ml}$ of $0.5 \%$ amyloglucosidase, buffered to $\mathrm{pH} \mathrm{4.9,} \mathrm{and} \mathrm{incubated} \mathrm{at}$ $38^{\circ} \mathrm{C}$ for $36 \mathrm{~h}$ (Smith 1981). Preliminary investigation indicated this time was sufficient for the enzyme to hydrolyze all disaccharides and starch. The samples were filtered, brought to $100 \mathrm{ml}$, and a $1.5-\mathrm{ml}$ aliquot was centrifuged at 16,000 rpm for $3 \mathrm{~min}$ to precipitate proteins. Carbohydrates in the extract were determined colorimetrically by adding $5 \mathrm{ml}$ of $80 \%(\mathrm{v} / \mathrm{v})$ phenol and $5 \mathrm{ml}$ of concentrated sulfuric acid to a $0.1-\mathrm{ml}$ aliquot of extract and incubated $0.3 \mathrm{~h}$ at $27^{\circ} \mathrm{C}$ as described by Dubois et al. (1956). Water soluble carbohydrates were extracted from separate 200 -mg samples in $80 \%(v / v)$ ethanol in water for $1 \mathrm{~h}$, filtered, and heated to remove the ethanol. Water soluble carbohydrates were determined colorimetrically as described previously. Insoluble carbohydrates were determined by subtracting the soluble carbohydrate content from the TNC for each sampling date. Carbohydrate analyses were repeated 3 times, and results are presented as milligrams carbohydrate per gram root dry weight.

The relationships between root soluble and insoluble carbohydrate content and average maximum and minimum air temperatures, mean air temperature, maximum dew point, total precipitation, and pan evaporation observed for 6 consecutive days (sampling and the previous days) were estimated by computing correlation coefficients. Also, the relationship between the water soluble and insoluble carbohydrate content and the daily mean temperature from 0 (sampling day) to 5 days prior to sampling and the average mean temperature (Day $0+1,0+1+2$, etc.) were estimated in 1983 and 1984 to determine when the correlation between temperature and carbohydrate content was highest. All environmental data were obtained from the National Weather Service in Fargo, N.D., located approximately $1 \mathrm{~km}$ from the research site. The data were analyzed using correlation and stepwise regression procedures (Statistical Analysis System Institute, 1982) to determine possible environmental influence on root carbohydrate content. Partial correlation coefficients $\left(\mathrm{rc}_{\mathrm{c}} \mathrm{E} \bullet \mathrm{T}\right)$ were calculated between carbohydrate levels $(C)$ and environmental variables $(E)$, holding time (T) statistically constant. The association between seasonal patterns of change in carbohydrate levels and environmental variables is assumed to be removed from the assessment of the association between short-term fluctuations in the same variables by holding time statistically constant.

Qualitative determination of the soluble carbohydrates was made by thin layer chromatography. Representative samples from May, July, and October of each growing season were extracted as previously described for soluble carbohydrates and spotted on thin layer plates coated with silica gel 60 impregnated with $0.02 \mathrm{M}$ sodium acetate. The plates were developed in ethyl acetate:isopropanol $(65: 35, \mathrm{v} / \mathrm{v})$. Spots were detected using an anisaldehydesulfuric acid spray reagent and identified with known sugar standards as described by Stahl (1969).

\section{Results and Discussion}

The TNC concentration of leafy spurge roots was lowest during early spring and averaged $150 \mathrm{mg} / \mathrm{g}$, but increased rapidly during spring growth and flower initiation to an average concentration of $300 \mathrm{mg} / \mathrm{g}$ or more in early to mid-July (Fig. 1). The TNC concentration generally declined during the summer dormancy period but

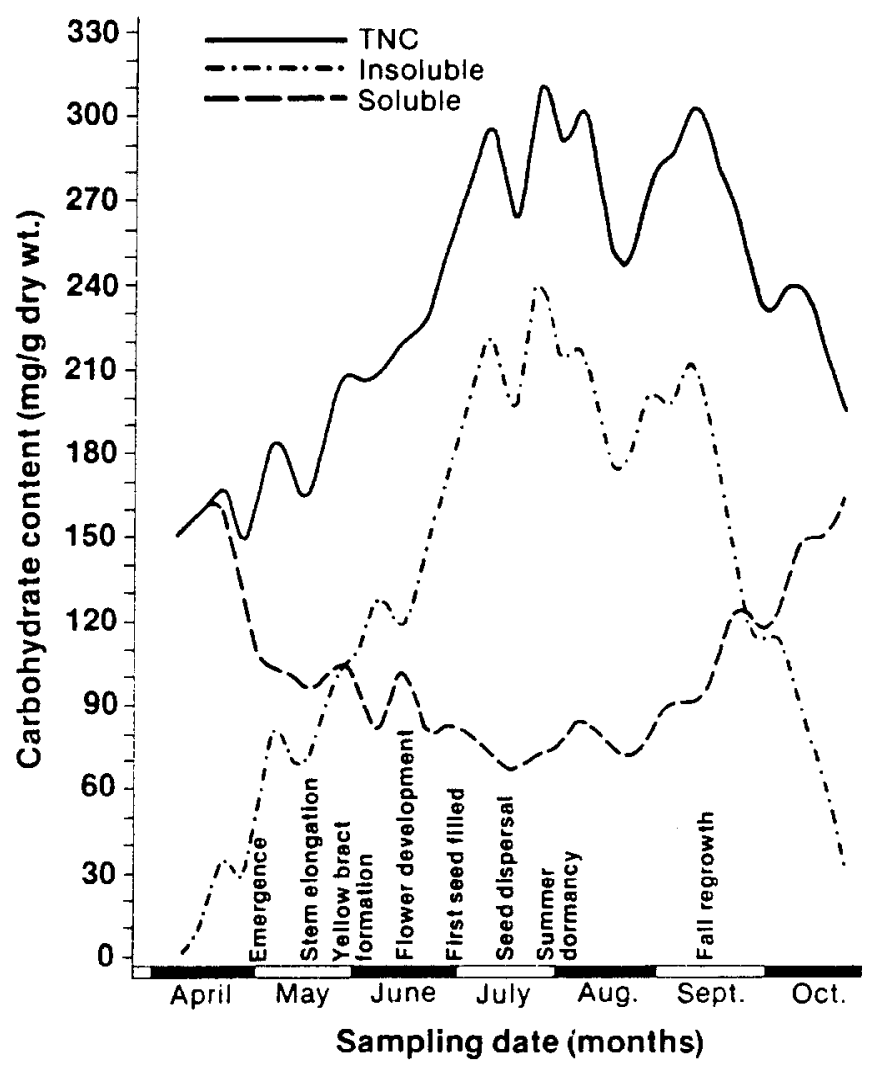

Fig. 1. Carbohydrate content of leafy spurge roots averaged over the 1981 through 1984 growing seasons indicating the TNC and the water soluble (sucrose) and the water insoluble components.

increased again to nearly $300 \mathrm{mg} / \mathrm{g}$ during fall regrowth. The TNC concentration then declined during cool fall weather and averaged only $190 \mathrm{mg} / \mathrm{g}$ when the plants' top growth was killed by freezing in late October.

The TNC pattern of leafy spurge roots did not follow that reported for other perennial weeds such as field bindweed (Convolvulus arvensis L.) and Canada thistle [Cirsium arvense (L.) Scop.] which are at a minimum level during seed maturation and reach maximum levels in the fall (Arny 1932, Barr 1940, Frazier 1943). This difference can be explained partially by differences in growth patterns between leafy spurge and many other perennial weeds. Leafy spurge is one of the first plants to emerge in the spring, and generally flowers develop in early June. Leafy spurge seeds often are physiologically mature in late June, which is much earlier in the growing season than many other perennial weeds. Thus, rapid carbohydrate storage in leafy spurge roots takes place following flowering and seed set as described for other perennial weeds, except these processes occur during early to mid-summer for leafy spurge rather than in late summer or early fall.

A decline in the TNC content of leafy spurge roots in late fall was unexpected (Fig. 1), but occurs in other herbaceous and woody 
plants (Li and Sakai 1982). This decline probably is associated with the winter hardening process. Leafy spurge top growth develops each spring from buds just below the soil surface (Best et al. 1980). These buds are dormant much of the growing season, but swell and elongate to near the soil surface just prior to freezing temperatures in the fall. The rapid fall bud growth could account for some but probably not all the decline in TNC in leafy spurge roots. Some carbohydrate loss also may be due to respiratory activity, but Siminovitch et al. (1954) have shown that it is difficult to account for all of the carbohydrates lost in plant cells during the fall-winter hardening process.

Nearly all the TNC content of leafy spurge roots was soluble carbohydrates in the early spring or fall, but nonsoluble starches predominated from mid-May to mid-September (Fig. 1). Maximum levels of soluble and insoluble carbohydrates averaged 166 $\mathrm{mg} / \mathrm{g}$ in October and $254 \mathrm{mg} / \mathrm{g}$ in mid-July, respectively. Thus, nonsoluble starches or reserve carbohydrates accounted for most of the TNC during the summer dormancy period, while soluble carbohydrate content was high during periods of growth or overwintering.

Sucrose was the major sugar in the soluble carbohydrate extract of leafy spurge roots when separated by thin layer chromatography. Minor amounts of maltose and fructose and a trace of glucose were present. Percentage of the various sugars in the soluble extract, based on diameter of thin layer chromatography spots, were similar during the entire growing season and did not vary with environmental changes. LeTourneau (1956) also found that sucrose was the predominant free sugar in the stems and leaves of leafy spurge, but he reported some glucose with a lesser amount of fructose.

The conversion of starches to sucrose has been reported for several plant species and often occurs early in the hardening process (Levitt 1980). Rapid and complete conversion of starch to sucrose has been reported for winter-hardy wheat (Triticum aestivum L.), but was much slower and incomplete in frost sensitive species (Rochat and Therrien 1975). Similar changes have been shown in barley (Hordeum vulgare L.) (Young and Feltner 1966), and higher sugar contents developed in winter-hardy than nonwinter-hardy rape (Brassica napus L.) (Hellstrom 1961). Sucrose is equal to ethylene glycol in increasing winter hardiness in woody plants and is much more effective than starch (Levitt 1980). It seems reasonable that the conversion of starches to sucrose later in the growing season is important for winter hardiness of leafy spurge roots in general and for elongation and winter survival of root buds in particular.

There was a general decline in maximum concentrations of TNC from $334 \mathrm{mg} / \mathrm{g}$ in 1981 to $190 \mathrm{mg} / \mathrm{g}$ in 1984 (Fig. 2). The reasons for the decline is not clear. The leafy spurge stand was well established and over 1 ha in area in 1981 when the sampling started, but the age of plants was not known. The stand increased in density and area during the experiment, but samples were obtained from undisturbed plants near the center of the original infestation. Perhaps the carbohydrate concentration of the roots $(\mathrm{mg} / \mathrm{g}$ basis) declined due to distribution of carbohydrates in a larger root system that developed over time, or nutrient availability in soil may have declined as the stand matured, or senescent effects due to increasing age of plants may result in reduced vigor. Sampling methods were similar in all years. The carbohydrate content was determined once the year's data were collected and twice at the end of the 4-year sampling period. Similar data were obtained for all 3 analyses. Precipitation, temperature, and length of growing season were somewhat different each year, but there were no patterns that explain the general decline observed in the carbohydrate content.

Soluble and insoluble carbohydrate contents changed abruptly from sampling date to date from mid-May to mid-August in all years (Fig. 2). More than a two-fold change in root soluble carbohydrate content was observed in some samples taken only 3 days apart in 1983 and 1984. The seasonal growth pattern of leafy spurge provided only a partial explanation for the abrupt fluctuations, but the changes may be environmentally dependent. Thus, the 6-day average maximum, minimum, and mean temperature, the average dew point, total pan evaporation, and precipitation

Table 1. Partial correlation of the water soluble and water insoluble nonstructural carbohydrate content in leafy spurge roots with various environmental parameters during 4 growing seasons.

\begin{tabular}{|c|c|c|c|c|c|c|}
\hline \multirow[b]{3}{*}{ Year and carbohydrate type } & \multicolumn{6}{|c|}{ Environmental parameters ${ }^{\star}$} \\
\hline & \multicolumn{3}{|c|}{ Temperature } & & \multirow{2}{*}{$\begin{array}{c}\text { Total pan } \\
\text { evaporation }\end{array}$} & \multirow[b]{2}{*}{ Precipitation } \\
\hline & Max. & Min. & Mean & Dew point & & \\
\hline & & 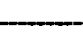 & (ב-ـ & 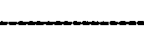 & 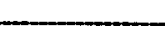 & \\
\hline $\begin{array}{l}1981 \\
\text { Water soluble } \\
\quad \text { Probability }\end{array}$ & $\begin{array}{r}-0.85 \\
0.01\end{array}$ & $\begin{array}{r}-0.90 \\
0.01\end{array}$ & $\begin{array}{r}-0.91 \\
0.01\end{array}$ & $\begin{array}{r}-0.57 \\
0.01\end{array}$ & $\begin{array}{r}-0.46 \\
0.18\end{array}$ & $\begin{array}{r}-0.07 \\
0.77\end{array}$ \\
\hline $\begin{array}{l}\text { Water insoluble } \\
\text { Probability }\end{array}$ & $\begin{array}{l}0.83 \\
0.01\end{array}$ & $\begin{array}{l}0.89 \\
0.01\end{array}$ & $\begin{array}{l}0.89 \\
0.01\end{array}$ & $\begin{array}{l}0.67 \\
0.01\end{array}$ & $\begin{array}{l}0.68 \\
0.26\end{array}$ & $\begin{array}{l}0.01 \\
0.83\end{array}$ \\
\hline $\begin{array}{l}1982 \\
\text { Water soluble } \\
\quad \text { Probability }\end{array}$ & $\begin{array}{r}-0.77 \\
0.01\end{array}$ & $\begin{array}{r}-0.81 \\
0.01\end{array}$ & $\begin{array}{r}-0.81 \\
0.01\end{array}$ & $\begin{array}{r}-0.83 \\
0.01\end{array}$ & $\begin{array}{r}-0.55 \\
0.01\end{array}$ & $\begin{array}{l}0.20 \\
0.38\end{array}$ \\
\hline $\begin{array}{l}\text { Water insoluble } \\
\text { Probabilty }\end{array}$ & $\begin{array}{l}0.87 \\
0.01\end{array}$ & $\begin{array}{l}0.84 \\
0.01\end{array}$ & $\begin{array}{l}0.88 \\
0.01\end{array}$ & $\begin{array}{l}0.61 \\
0.01\end{array}$ & $\begin{array}{l}0.74 \\
0.01\end{array}$ & $\begin{array}{r}-0.08 \\
0.64\end{array}$ \\
\hline $\begin{array}{l}1983 \\
\text { Water soluble } \\
\quad \text { Probability }\end{array}$ & $\begin{array}{r}-0.73 \\
0.01\end{array}$ & $\begin{array}{r}-0.73 \\
0.01\end{array}$ & $\begin{array}{r}-0.74 \\
0.01\end{array}$ & $\begin{array}{r}-0.65 \\
0.01\end{array}$ & $\begin{array}{r}-0.19 \\
0.24\end{array}$ & $\begin{array}{r}-0.05 \\
0.73\end{array}$ \\
\hline $\begin{array}{l}\text { Water insoluble } \\
\text { Probability }\end{array}$ & $\begin{array}{l}0.62 \\
0.01\end{array}$ & $\begin{array}{l}0.65 \\
0.01\end{array}$ & $\begin{array}{l}0.65 \\
0.01\end{array}$ & $\begin{array}{l}0.63 \\
0.01\end{array}$ & $\begin{array}{l}0.37 \\
0.01\end{array}$ & $\begin{array}{l}0.03 \\
0.94\end{array}$ \\
\hline $\begin{array}{l}1984 \\
\text { Water soluble } \\
\quad \text { Probability }\end{array}$ & $\begin{array}{r}-0.61 \\
0.01\end{array}$ & $\begin{array}{r}-0.43 \\
0.01\end{array}$ & $\begin{array}{r}-0.54 \\
0.01\end{array}$ & $\begin{array}{r}-0.43 \\
0.01\end{array}$ & $\begin{array}{l}0.25 \\
0.08\end{array}$ & $\begin{array}{l}0.12 \\
0.38\end{array}$ \\
\hline $\begin{array}{l}\text { Water insoluble } \\
\text { Probability }\end{array}$ & $\begin{array}{l}0.78 \\
0.01\end{array}$ & $\begin{array}{l}0.61 \\
0.01\end{array}$ & $\begin{array}{l}0.73 \\
0.01\end{array}$ & $\begin{array}{l}0.45 \\
0.01\end{array}$ & $\begin{array}{r}-0.31 \\
0.67\end{array}$ & $\begin{array}{r}-0.21 \\
0.54\end{array}$ \\
\hline
\end{tabular}

Environmental parameters are an average for 6 days, i.e. the sampling day plus the 5 days prior to sampling.

bartial correlation coefficient for carbohydrate and environmental parameter with time held statistically constant. 


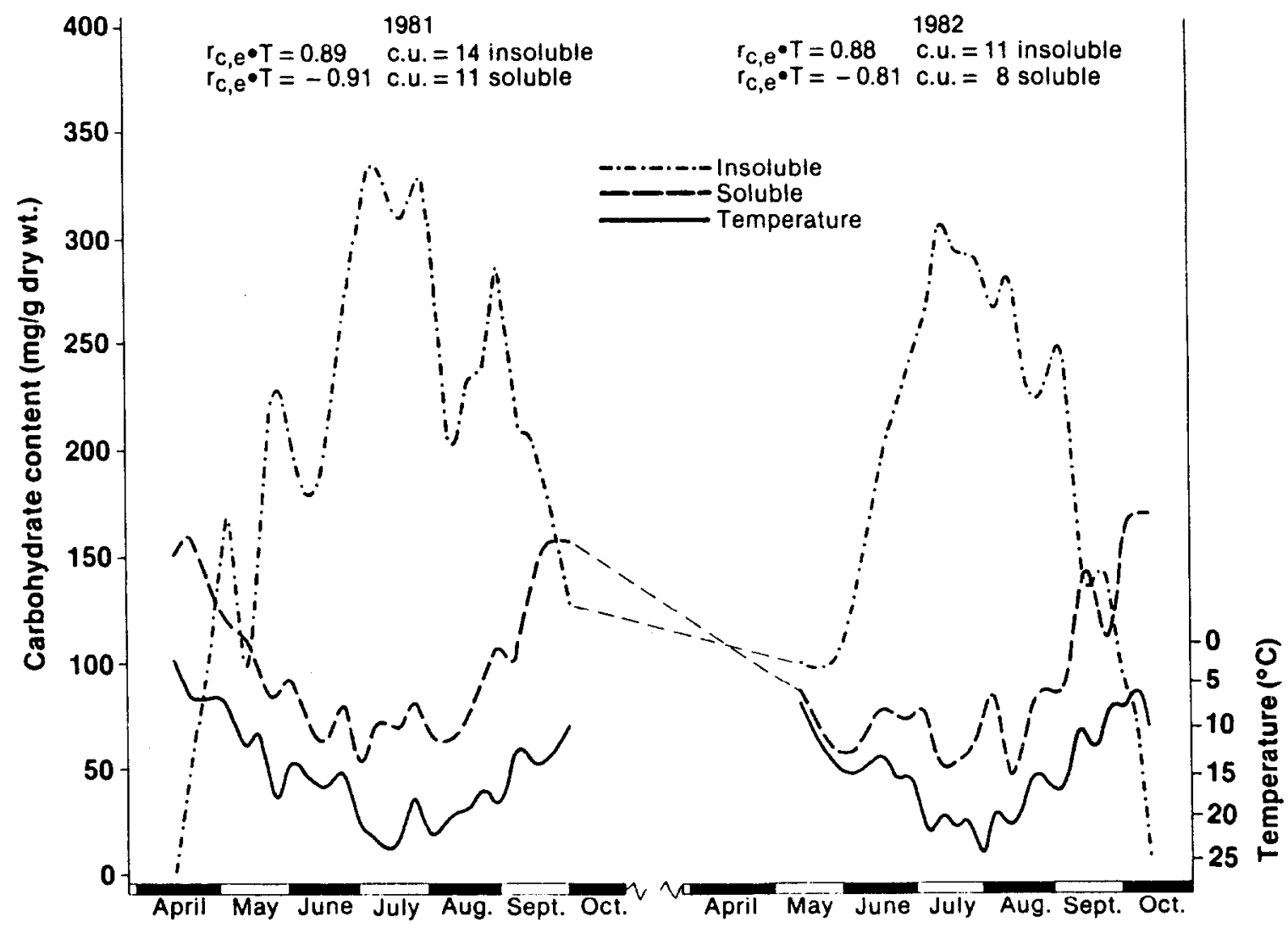

FIGURE 2A.

Sampling date (months)

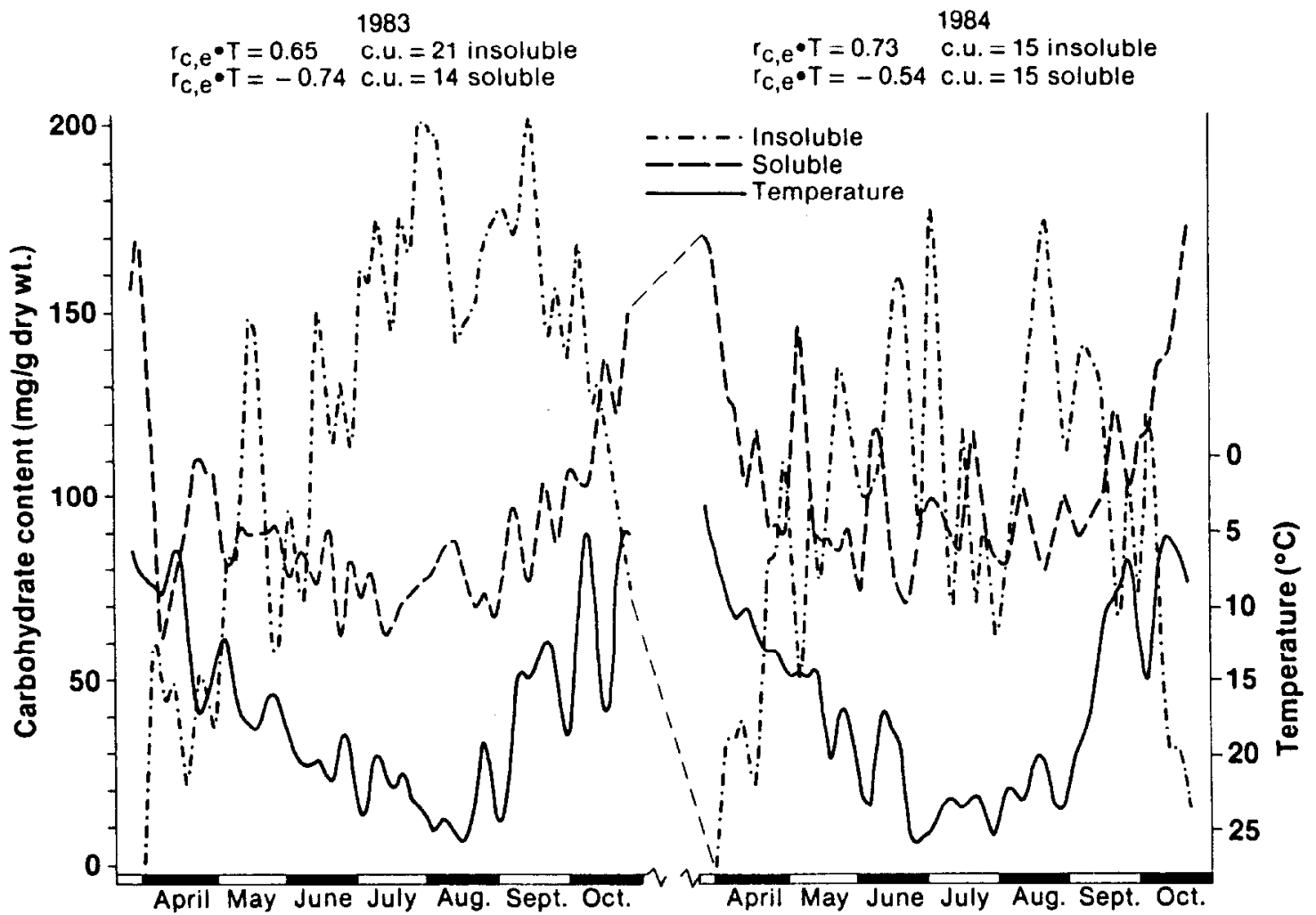

FIGURE 2B.

\section{Sampling date (months)}

Fig. 2. Leafy spurge root insoluble and soluble carbohydrate content versus the mean air temperature during the 1981 through 1984 growing seasons. Samples were obtained at weekly intervals in 1981 and 1982 (A) and twice per week in 1983 and 1984 (B). Temperatures are plotted as $100-(C X 4)$ to obtain a scale similar to the carbohydrate plot which enhances visual comparisons, but the correlations were calculated using actual temperatures which results in negative correlations. 
values were calculated for the period prior to each sampling date and compared to the soluble and insoluble carbohydrate content.

Soluble carbohydrate content varied inversely to changes in the weekly mean temperatures with a partial correlation coefficient of $-0.91,-0.81,-0.74$, and -0.54 in $1981,1982,1983$, and 1984 , respectively (Table 1 and Fig. 2). The correlation coefficients declined from year to year in a manner similar to the general decline in total root carbohydrate content from 1981 through 1984. Similar correlations were found between the average maximum or minimum temperature and leafy spurge root soluble carbohydrate content (Table 1). In general, the root soluble carbohydrate content decreased as the temperature increased and increased when temperature decreased.

The insoluble carbohydrate content also varied with changes in the air temperature, except the correlations were positive (Table 1). The insoluble carbohydrate content increased with periods of increasing temperature, and decreased as temperatures declined (Fig. 2). The partial correlation coefficients between mean temperature and insoluble carbohydrate content were $0.89,0.88,0.65$ and 0.73 in 1981, 1982, 1983, and 1984, respectively (Table 1). Similar partial correlations were found between the average maximum or minimum temperature and the leafy spurge root insoluble carbohydrate content.

Changes in air temperature rather than a specific temperature influenced root carbohydrate content. For example, in 1981 an increase in the weekly mean temperature from 16 to $21^{\circ} \mathrm{C}$ in mid-June corresponded to a decrease in soluble carbohydrate concentration from 80 to $54 \mathrm{mg} / \mathrm{g}$ (Fig. 2). Whereas, in late July, a decrease in mean temperature from 23 to $19^{\circ} \mathrm{C}$ corresponded to an increase in the soluble carbohydrate concentration from 71 to 83 $\mathrm{mg} / \mathrm{g}$. Carbohydrate root reserves in Kentucky bluegrass also have fluctuated with temperature changes (McKell et al. 1969). Fructose accumulation was greatest at $13-7^{\circ} \mathrm{C}$ day-night temperature, but fructose reserves were depleted rapidly when the temperature was increased to $30-18^{\circ} \mathrm{C}$ day-night for 2 weeks. Root carbohydrate content in white clover (Trtfolium repens L.) increased during periods of low temperature, and also was influenced by ecotype and photoperiod (Boller and Nosberger 1983).

Root samples were taken twice weekly in 1983 and 1984 to better define when temperature may have the greatest effect on carbohydrate content. In general, the partial correlation coefficients increased slightly as the period of time used to calculate the mean increased and was consistently highest with a time period of 6 days (data not shown). For example, the partial correlation between soluble carbohydrates and average mean temperature in 1983 was $-0.66(P=0.01)$ one day prior to sampling but was $-0.74(P=0.01)$ when correlated with the average mean temperature 6 days prior to sampling. The pattern was similar for both water soluble and insoluble carbohydrates, except the soluble carbohydrates varied inversely to changes in the mean temperature.

The dew point and total pan evaporation are indicators of water content of the air and perhaps would serve as indirect indicators of plant water stress. The dew point and pan evaporation varied inversely to changes in root soluble carbohydrate content and directly with insoluble carbohydrate content (Table 1). The coefficients were less than, but similar in pattern to, the correlations between temperature and carbohydrate; similar coefficients were expected since dew point and pan evaporation are strongly influenced by temperature. Dew point was a more consistent indicator of carbohydrate fluctuations than total pan evaporation when considering partial correlation coefficients for all years, but neither indicator was as good as temperature alone.

Fluctuations in carbohydrate content were independent of rainfall during the growing season (Table 1). The independence of leafy spurge carbohydrate metabolism from short-term fluctuations in soil moisture is likely because of the deep leafy spurge root system, which can utilize water in the soil profile to a depth of at least $4.5 \mathrm{~m}$ (Barr 1940).
The high correlation between fluctuations in temperature and carbohydrate content may indicate that the flow of photosynthate in leafy spurge is affected quickly by changes in the environment. The soluble carbohydrate content in the root decreased as the average temperature increased, and conversely, the soluble carbohydrate content increased when the average temperature decreased. Thus, the leafy spurge plant seems to utilize stored soluble carbohydrates during stress periods such as increasing temperature, but begins restoring the soluble carbohydrates when temperatures cool and the plant is under less stress. Because auxin-type herbicides such as 2,4-D [(2,4-dichlorophenoxy)acetic acid] often are translocated in the phloem with photosynthate (Crafts 1956), the environment-photosynthate flow relationship could influence herbicide translocation in leafy spurge. Herbicide application during cooler weather immediately after a warm period when downward photosynthate flow in leafy spurge increases may result in increased herbicide translocation to the root system and a longer period of acceptable control.

Movement of soluble carbohydrates is a complex process and is not totally dependent upon temperature change. Although the general trend of carbohydrate flow followed the leafy spurge growth cycle, the sharp fluctuations in root carbohydrate content during flower development, seed maturation, and summer dormancy seemed largely because of environmental factors. Study of environmental influences on soluble carbohydrate and herbicide flow in leafy spurge and other perennial plants could lead to more precise timing of herbicide application to coincide with downward carbohydrate and herbicide translocation to the root system. A disruption in the conversion of insoluble starches to sucrose by herbicides or plant growth regulators in leafy spurge roots during the fall may increase the plant's susceptibility to winterkill.

\section{Literature Cited}

Agbakoba, C.S.O., and J.R. Goodin. 1969. Effects of stage of growth of field bindweed on absorption and translocation of ${ }^{4} \mathrm{C}$-labeled 2,4D and picloram. Weed Sci. 17:436-438.

Amy, A.C. 1932. Variations in the organic reserves in underground parts of five perennial weeds from late April to November. Minn. Agr. Exp. Sta. Tech. Bull. 84

Bakke, A.L. 1936. Leafy spurge, Euphorbia esula L. Iowa Agr. Exp. Sta. Bull. 198.

Barr, C.G. 1940. Organic reserves in the roots of bindweed. J. Agr. Res. 60:391-413.

Barr, C.G. 1942. Reserve foods in the roots of whiteweed (Cardaria draba var. repens). J. Agr. Res. 64:725-740.

Best, K.F., G.G. Bowes, A.G. Thomes, and M.G. Maw. 1980. The biology of Canadian weeds. Euphorbia esula L. Can. J. Plant Sci. 60:651-663.

Boller, B.C., and J. Nosberzer. 1983. Effects of temperature and photoperiod on stolon characteristics, dry matter partitioning, and nonstructural carbohydrate concentration of two white clover ecotypes. Crop Sci. 23:1057-1062.

Bybee, T.A. 1979. Factors affecting leafy spurge control including leafy spurge reestablishment, herbicide application dates, herbicide translocation, and root carbohydrates. Ph.D. Thesis North Dakota State Univ. Univ. Microfilms. Ann Arbor, Mich. (Diss. Abst. 7922217).

Chang, F.Y., and W.H. VandenBorn. 1968. Translocation of dicamba in Canada thistle. Weed Sci. 16:176-181.

Crafts, A.S. 1956. Translocation of herbicides. II. Absorption and translocation of 2,4-D by wild morning-glory. Hilgardia 26:335-365.

Dubois, M.K., K.A. Gilles, J.K. Hamilton, P.A. Rebers, and F. Smith. 1956. Colorimetric method for determination of sugars and related substances. Anal. Chem. 28:350-356.

Frazier, J.C. 1943. Amount, distribution and seasonal trend of certain organic reserves in the root system of field bindweed. Plant Physiol. 18:167-184.

Hellstrom, N. 1961. Investigations on oil turnips and oil rape. VIII. On Sugar and Protein Content in Two Varieties of Oil Rape. Acta. Agr. Scand. 11:151-159.

Hunter, J.H., and G.I. MeIntyre. 1974. Factors affecting translocation of 2,4-D in leafy spurge. Weed Sci. 22:167-171.

LeToumeau, D. 1956. A note on the sugars and amino acids of leafy spruge, (Euphorbia esula L.). Weeds 4:275-277. 
Levitt, J. 1980. Responses of plants to environmental stress. Vol. I. Chilling, freezing and high temperature stresses. Academic Press, New York.

L, P.H., and A. Sakni. 1982. Plant cold hardiness and freezing stress. Vol. II. Academic Press, New York.

Mellroy, R.J. 1967. Carbohydrates of grassland herbage. Herbage Abs. 37:79-87.

McKell, C.M., V.B. Youngner, F.J. Nudge, and N.J. Chatterton. 1969. Carbohydrate accumulation of coastal bermudagrass and Kentucky bluegrass in relation to temperature regimes. Crop Sci. 9:534-537.

Rochat, E., and H.P. Therrien. 1975. Ultramicroscopic study of the cytologic modifications in winter wheat during the hardening process to cold weather. Can. J. Bot. 53:2411-2416.

Sharma, M.P., F.Y. Chang, and W.H. VandenBorn. 1971. Penetration and translocation of picloram in Canada thistle. Weed Sci. 19:349-355.
Siminovitch, D., and D.R. Briges. 1954. Studies on the chemistry of the living bark of the black locust in relation to its frost hardiness. Plant Physiol. 29:331-337.

Smith, D.1970. Influence of temperature on the yield and chemical composition of five forage legume species. Agron. J. 62:520-523.

Smith, D. 1981. Removing and analyzing total nonstructural carbohydrates from plant tissue. Univ. Wisconsin Res. Rep. No. 2107.

Stahl, E. 1969. Thin layer chromatography. 2nd Ed. Springer-Verlag, New York.

Statistical Analysis System Institute. 1982. SAS User's Guide: Statistics. Cary, N.C.

Young, A.L., and K.C. Feltner. 1966. Managerial and physiological factors influencing the winter hardiness of barley in Wyoming. Crop Sci. $6: 547-551$ 